\title{
A Case Report of Multiple Cylindroma with Immunohistochemical Features
}

\author{
Naoki Watanabe1, Kana Kawase2, Chisato Tawada², Kazufumi Yoneda², Kuniaki Hirai3, \\ Ayumi Niwa1, Takuji Tanaka ${ }^{*}$ \\ ${ }^{1}$ Department of Diagnostic Pathology (DDP) \& Research Center of Diagnostic Pathology (RC-DiP), Gifu \\ Municipal Hospital, Gifu City, Japan \\ ${ }^{2}$ Department of Dermatology, Gifu Municipal Hospital, Gifu City, Japan \\ ${ }^{3}$ Department of Radiology, Ehime University Graduate School of Medicine, Shitsukawa, Toon City, Japan \\ Email: *takutt@gmhosp.gifu.Gifu.jp
}

Received 10 March 2016; accepted 26 June 2016; published 29 June 2016

Copyright (C) 2016 by authors and Scientific Research Publishing Inc.

This work is licensed under the Creative Commons Attribution International License (CC BY).

http://creativecommons.org/licenses/by/4.0/

c) (i) Open Access

\begin{abstract}
Cylindroma is a benign skin appendageal tumor arising from pluripotent stem cells in the follicle. Multiple cylindroma typically occurs as a component of Brooke-Spiegler syndrome or as the only skin lesion of familial cylindromatosis. We herein report an unusual case of multiple cylindroma involving the trunk without any other features of Brooke-Spiegler syndrome and no family history supporting the possibility of familial cylindromatosis. Immunohistochemical features of CYLD and $\mathrm{NF}-\kappa \mathrm{B}$, which are involved in the pathogenesis of cylindroma, in the tumors are also presented.
\end{abstract}

\section{Keywords}

\section{Multiple Cylindroma, Immunohistochemistry, CYLD, NF- $\kappa B$}

\section{Introduction}

Cylindroma is a benign cutaneous tumor arising from pluripotent stem cells in the hair follicles [1] [2]. Cylindroma most often affects the scalp, with a strong predilection for middle-aged and elderly females [2]. It occurs more often as a solitary lesion [3]. Cylindromas may also occur in less than $10 \%$ of cases in the trunk and limbs [4]. This neoplasm is generally asymptomatic, but some patients may experience pain [4]. Cases with multiple lesions tend to be dominantly inherited [3] [5] and clinically present as multiple, smooth, firm, pink to red, somewhat pedunculated nodules of various sizes [4]. In such cases, new tumors continue to develop over time. However, malignant transformation of multiple or solitary cutaneous cylindroma rarely occurs [5].

${ }^{*}$ Corresponding author.

How to cite this paper: Watanabe, N., Kawase, K., Tawada, C., Yoneda, K., Hirai, K., Niwa, A. and Tanaka, T. (2016) A Case Report of Multiple Cylindroma with Immunohistochemical Features. Open Journal of Pathology, 6, 134-139.

http://dx.doi.org/10.4236/ojpathology.2016.63016 
The histogenesis of cutaneous cylindroma has remained a subject of intense and controversial debate [1] [2] [6]. However, a previous immunostaining study by Massoumi et al. [2] suggested that cylindroma likely originates from the epithelial hair follicle, whose precise differentiation pathway may be dictated by the nature of epithelial-mesenchymal signaling. A recent immunohistochemical study with CD200 and other stemcell markers has also indicated the hair follicle to be the origin of cylindroma [1].

Although Brooke-Spiegler syndrome (BSS), familial cylindromatosis (FC) and multiple familial trichoepithelioma (MFT) were originally described as distinct entities, these diseases show overlapping phenotypic features. Different manifestations of each disease have been reported in a single family. Therefore, these three disorders are considered to represent a phenotypic spectrum of a single disease entity [7]. The fact that mutation in a single CYLD gene is responsible for all these three syndromes strengthens the concept [5] [7] [8]. Loss of CYLD enhances Wnt/ $\beta$-catenin signaling in cylindroma [9]. In addition, CYLD negatively regulates nuclear factor-kappaB (NF- $\kappa \mathrm{B}$ ) activation [10]. Multiple cylindromas without the other components of BSS is extremely rare [11].

We herein report an unusual case of multiple cylindroma, which developed in the trunk (chest, shoulder, and back) of an 84-year-old Japanese woman without any other feature of BSS and no family history supporting the possibility of FC. Immunohistochemical features, including CYLD and NF- $\kappa \mathrm{B}$ that are involved in the pathogenesis of cylindroma, in the tumors are also presented.

\section{Case Report}

An 84-year-old Japanese woman presented with multiple asymptomatic swellings in the back, shoulder (bilateral), and chest (right breast) for the previous 74 years with an increase in size and number over time. Some lesions grew significantly and changed in color within the last 6 months, which prompted the patient to seek our consultation. She noticed skin tumors (back and right breast) from approximately 10 years of age, but did not receive treatment. There was no history of similar lesions in any of her family members.

On examination, multiple, rounded, smooth surfaced, firm, non-tender, and freely mobile skin-colored to reddish papules and tumorous nodules of varying sizes $(3 \mathrm{~mm}$ to $20 \mathrm{~mm}$ ) were observed on the left back (Figure 1), bilateral shoulder, and right anterior chest. A total of 8 tumors or nodules were noticed during the previous 15 years. Because the color of the lesions became reddish and their size increased, the patient wanted to remove them. No lesions were found on her scalp. There were no abnormalities in other areas of the skin, mucosa, nails, or hair.

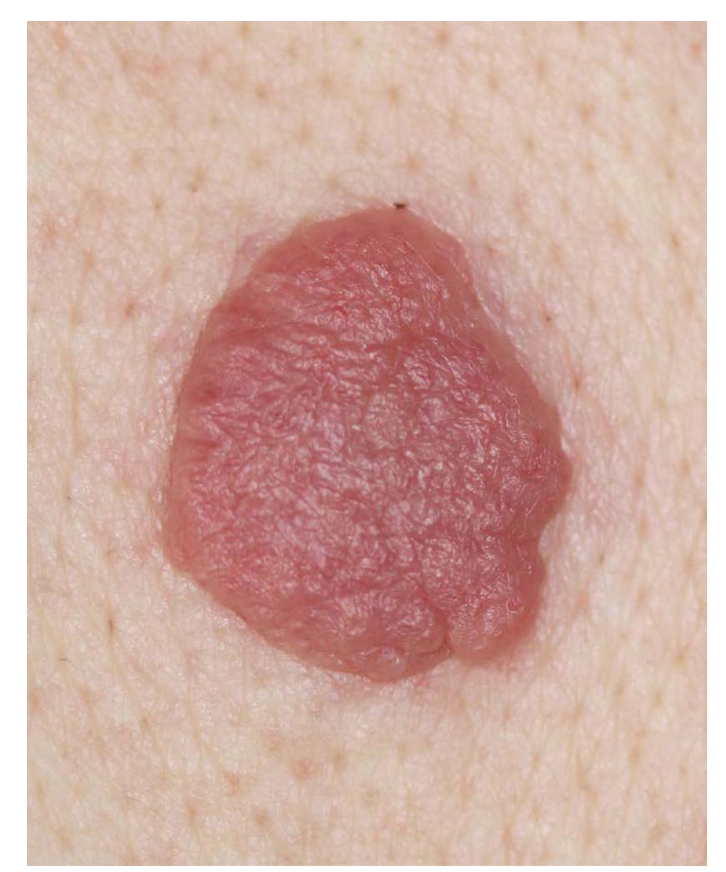

Figure 1. A confluent erythematoustelangiectatic noduleon the left back,suggestive of cylindroma or spiradenocylindroma. 
Histopathology: Surgical excision of the tumorous nodules revealed a non-encapsulated tumor composed of closely set tumor lobules forming mosaic-like masses with a jigsaw-puzzle appearance. The tumor lobules were separated from one another by thin bands of hyaline material (Figure 2(a)). On higher magnification, two types of cells were observed: larger cells with a moderate amount of cytoplasm and a vesicular nucleus in the center of the tumor island and small cells with little cytoplasm and compact nuclei in the periphery (Figure 2(b)). The peripheral cells showed a tendency toward palisading. The small cells were observed surrounding duct-like spaces and masses of hyaline material, which was positive for PAS staining (Figure 2(c)) and stained blue with Alcian blue (Figure 2(d)) within a few tumor lobules. According to the histopathological findings, a diagnosis of cylindroma for all lesions was made.

Immunohistochemistry: Immunohistochemically, some cylindroma cells were positive for estrogen receptor (ER, Figure 2(a)), progesterone receptor (PgR, Figure 3(b)), and S-100 (Figure 3(c)). However, all tumors cells were negative for GCDFP15 (Figure 3(d)). Cell membranes, but not the nuclei, were immunohistochemically positive for $\beta$-catenin (Figure 3(e)). Regarding other antibodies, the tumor cells were negative for CEA, CK20 and EMA (data not shown). The nuclei of the peripheral cells were positive for CYLD immunohistochemistry (Figure 3(f)), as observed in the apocrine glands (inset in Figure 3(f)). NF- $\kappa$ B immunohistochemistry showed positive reactions in the nucleus and cytoplasm of cylindroma cells peripherally and centrally located in the tumor islands (Figure 3(g)). Approximately 50\% of the tumor cells were positive for p53 (Figure 4(a)) and the MIB-1-positive index was 5\% - 10\% (Figure 4(b)).

\section{Discussion}

Multiple cylindromas are generally observed as a component of BSS or as the only skin lesion of FC. The typical site of occurrence is the scalp. Cutaneous cylindroma shows two different clinical presentations, solitary and multiple [5]. Solitary cylindromas lowly grows and mainly develops in the scalp, especially the capillitium and neck region. Multiple cylindromas are inherited in an autosomal dominant pattern and frequently occur on the scalp and rarely on the trunk [12]. The term "turban tumor", which can cover the entire scalp, is used to describe

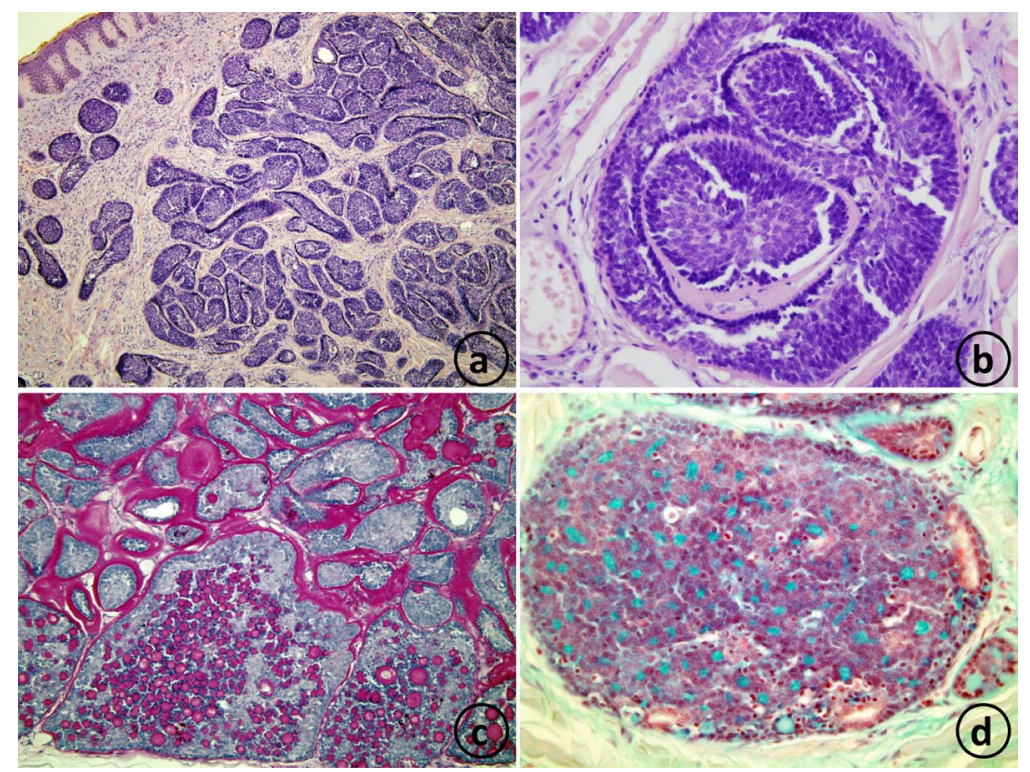

Figure 2. A microscopic view of the tumors. (a) A non-encapsulated subcutaneous tumor composed of closely set tumor lobules forming mosaic-like masses with a jigsaw-puzzle appearance; (b) Two types of basaloid cells constitute the islands: relatively undifferentiated cells with small, dark-staining nuclei present predominantly at the periphery of the islands, often in a palisade arrangement and more differentiated cells with large, light-staining nuclei present in the center of the islands; (c) The tumor lobules are separated from one another by thin bands of hyaline material, which are positive for PAS staining; (d) Small tubular lumina lined by cells that typically have the appearance of ductal cells are observed in some parts. The lumina containmasses of hyaline material, which stained blue with Alcian blue. (a) H\&E stain, 50×; (b) H \& E stain, 200×; (c) PAS stain, 200×; and (d) Alcian blue stain, 200×. 


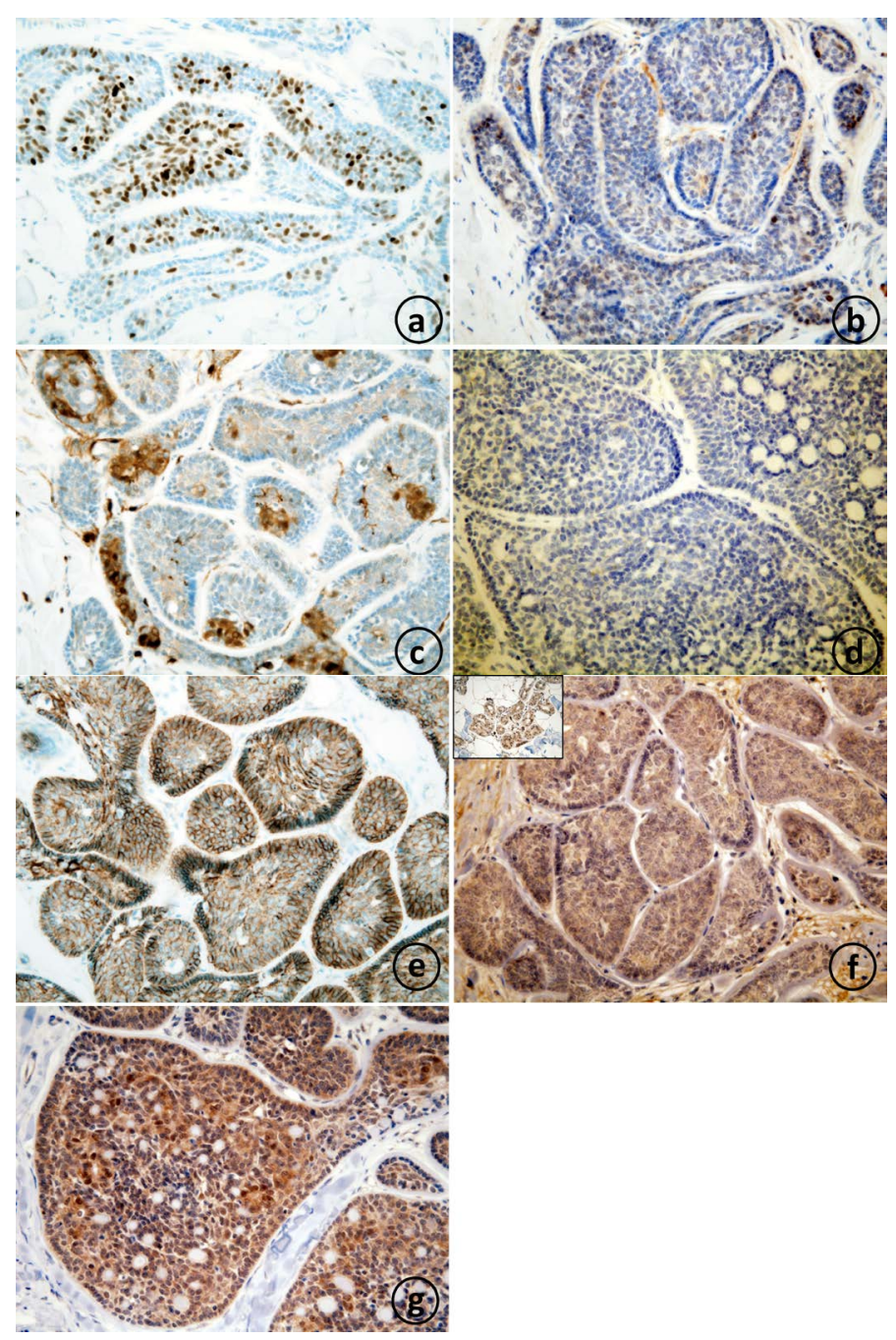

Figure 3. Immunohistochemistry of (a) ER, (b) PgR, (c) S-100, (d) GCDFP15, (e) $\beta$-catenin, (f) CYLD, and (g) NF- $\kappa$ B. Some tumors cells reacted against these antibodies, except GCDFP15. Inset in (f) shows a nuclear positive reaction of CYLD in the apocrine gland cell nuclei. (a)-(g), 200×.

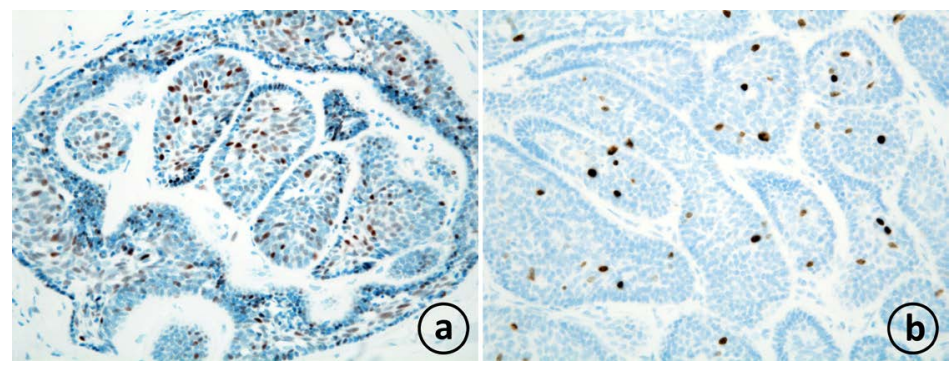

Figure 4. Immunohistochemistry of (a) p53 and (b) MIB-1. (a) and (b), 200×.

the localization of the tumor and its pathognomonic size [5].

Cylindromas are generally found as small solitary lesions on the head and neck. A rarer variant with multiple lesions in a linear array has been reported. Multiple cylindroma occurs in FC (OMIM\#132700) and BSS (OMIM\#605041), in which multiple familial trichoepithelioma (MFT, OMIM \#601606) are associated with multiple cylindromas and occasionally spiradenoma or spiradenoma/cylindroma overlap lesions [13]. This association is compelling evidence for the folliculo-sebaceous-apocrine origin of these various tumors. They are dif- 
ferent phenotypic expressions of mutations in the same gene, the CYLD gene on chromosome 16q12-q13. Germline mutations in the CYLD gene were originally identified in patients with FC [14]. In addition to this type of skin tumor, CYLD can act as a tumor suppressor gene in other human cancers [15]. Interestingly, $\beta$-catenin is elevated in the nuclei of cylindroma cells [9]. Sustained Wnt-mediated $\beta$-catenin nuclear translocation was shown to enhance proliferation of cylindroma cells [9]. Down-regulation of CYLD in this pathway thus promotes $\beta$-catenin accumulation in the nucleus. In the present report, we noted a case of multiple cylindromas occurring unusually only on the face without any other clinical or histopathological components of BSS in an elderly women. The onset of her tumors at 84 years of age is well beyond the age of occurrence of skin lesions of BSS or FC. Because a careful family pedigree did not reveal any other family member with similar skin lesions, we describe this condition as multiple non-familial cylindromatosis.

Malignant transformation rarely occurs in cylindroma [5]. The malignant differentiation tendency is higher in the multiple type of cylindroma, as compared to the solid type [16]. In the present case, we did not observe nuclear staining of $\beta$-catenin immunohistochemistry. Additionally, the MIB-1 index (5\% - 10\%) was relatively low. These findings suggest that our case does not possess the potential of malignant transformation.

The pathogenesis of cylindroma remains controversial. The Armed Forces Institute of Pathology (AFIP) promoted an eccrine derivation [17]-[19] that has been reiterated up to recently by studies employing immunohistochemical methods [20]-[23]. However, previous immunohistochemical studies used antibodies directed against antigens found in various tissues, including cytokeratins (CK6, CK7, CK10), CD10, CD15, CD34, CD44, carcinoembryonic antigen, smooth muscle antigen and S100 [20]-[23]. Thus, oppositional research against an eccrine derivation of cylindroma was demonstrated in electron microscopic studies that favored an apocrine lineage [24] [25]. Despite the widely accepted view of cylindroma as an eccrine tumor, there are strong arguments that favor a derivation from the folliculo-sebaceous-apocrine unit. Mutations in a tumor suppression gene, CYLD, on chromosome 16q12-q13 are responsible for cylindroma development through constitutive NF- $\kappa$ B activation [2]. In the present case, cylindroma cells were immunohistochemically positive for CYLD and NF- $\kappa$ B.

There is currently no curative therapy available for multiple cylindroma, however, surgical excision or laser ablation is the treatment of choice for multiple cylindroma [26] [27]. A therapeutic approach has recently been attempted to treat single cylindroma in BSS with topically applied salicylic acid at varying concentrations. Salicylic acid acts by interfering the NF- $\kappa$ B signaling pathway [27].

\section{Conclusion}

Cylindroma develops from pluripotent stem cells in the follicle. Multiple cylindromas typically occur as a component of BSS or as the only skin lesion of familial cylindromatosis. We herein report an unusual case of multiple non-familial cylindromas involving the trunk. The tumor cells were immunohistochemically positive for $\mathrm{NF}-\kappa \mathrm{B}$ and those located in the periphery were positive for CYLD. Our case suggests possible involvement of CYLD in non-familial cylindroma and potential new therapeutic strategy against tumors associated with abnormal expression of CYLD and NF- $\kappa \mathrm{B}$.

\section{References}

[1] Sellheyer, K. (2015) Spiradenoma and Cylindroma Originate from the Hair Follicle Bulge and Not from the Eccrine Sweat Gland: An Immunohistochemical Study with CD200 and Other Stem Cell Markers. Journal of Cutaneous Pathology, 42, 90-101. http://dx.doi.org/10.1111/cup.12406

[2] Massoumi, R., Podda, M., Fassler, R. and Paus, R. (2006) Cylindroma as Tumor of Hair Follicle Origin. Journal of Investigative Dermatology, 126, 1182-1184. http://dx.doi.org/10.1038/sj.jid.5700218

[3] Klein; W., Chan, E. and Seykora, J.T. (2005) Tumors of the Epidermal Appendages. In: Elder, D.E., Elenitsas, R., Johnson B.L. and Murphy, G.F., Eds., Lever’s Histopathology of the Skin, Lippincott Williams \& Wilkins, Philadelphia, 897-898.

[4] Calonje, E. (2010) Tumours of the Skin Appendages. In: Burns, T., Breathnach, S., Cox, N. and Griffiths, C., Eds., Rook's Textbook of Dermatology, Wiley-Blackwell, Singapore, 28-53. http://dx.doi.org/10.1002/9781444317633.ch53

[5] Rajan, N. and Ashworth, A. (2015) Inherited Cylindromas: Lessons from a Rare Tumour. The Lancet Oncology, 16, e460-e469. http://dx.doi.org/10.1002/9781444317633.ch53

[6] Saga, K. (2001) Histochemical and Immunohistochemical Markers for Human Eccrine and Apocrine Sweat Glands: An Aid for Histopathologic Differentiation of Sweat Gland Tumors. Journal of Investigative Dermatology. Symposium Proceedings, 6, 49-53. http://dx.doi.org/10.1046/j.0022-202x.2001.00005.x 
[7] Blake, P.W. and Toro, J.R. (2009) Update of Cylindromatosis Gene (CYLD) Mutations in Brooke-Spiegler Syndrome: Novel Insights into the Role of Deubiquitination in Cell Signaling. Human Mutation, 30, 1025-1036. http://dx.doi.org/10.1002/humu.21024

[8] Bowen, S., Gill, M., Lee, D.A., Fisher, G., Geronemus, R.G., Vazquez, M.E. and Celebi, J.T. (2005) Mutations in the CYLD Gene in Brooke-Spiegler Syndrome, Familial Cylindromatosis, and Multiple Familial Trichoepithelioma: Lack of Genotype-Phenotype Correlation. Journal of Investigative Dermatology, 124, 919-920. http://dx.doi.org/10.1111/j.0022-202X.2005.23688.x

[9] Tauriello, D.V., Haegebarth, A., Kuper, I., Edelmann, M.J., Henraat, M., Canninga-van Dijk, M.R., Kessler, B.M., Clevers, H. and Maurice, M.M. (2010) Loss of the Tumor Suppressor CYLD Enhances Wnt/Beta-Catenin Signaling through K63-Linked Ubiquitination of Dvl. Molecular Cell, 37, 607-619. http://dx.doi.org/10.1016/j.molcel.2010.01.035

[10] Sun, S.C. (2010) CYLD: A Tumor Suppressor Deubiquitinase Regulating NF-kappaB Activation and Diverse Biological Processes. Cell Death \& Differentiation, 17, 25-34. http://dx.doi.org/10.1038/cdd.2009.43

[11] Woodon, D. (2010) Cylindroma. In: Weedon, D., Ed., Weedon's Skin Pathology, Churchill Livingstone Elsevier, London, 785-786.

[12] Durani, B.K., Kurzen, H., Jaeckel, A., Kuner, N., Naeher, H. and Hartschuh, W. (2001) Malignant Transformation of Multiple Dermal Cylindromas. British Journal of Dermatology, 145, 653-656. http://dx.doi.org/10.1046/j.1365-2133.2001.04460.x

[13] Weedon, D. (2010) Tumors of Cutaneous Appendages. In: Weedon, D., Ed., Weedon's Skin Pathology, Churchill Livingstone Elsevier, China, 785-786. http://dx.doi.org/10.1016/b978-0-7020-3485-5.00034-6

[14] Bignell, G.R., Warren, W., Seal, S., Takahashi, M., Rapley, E., Barfoot, R., Green, H., Brown, C., Biggs, P.J., Lakhani, S.R., Jones, C., Hansen, J., Blair, E., Hofmann, B., Siebert, R., Turner, G., Evans, D.G., Schrander-Stumpel, C., Beemer, F.A., van Den Ouweland, A., Halley, D., Delpech, B., Cleveland, M.G., Leigh, I., Leisti, J. and Rasmussen, S. (2000) Identification of the Familial Cylindromatosis Tumour-Suppressor Gene. Nature Genetics, 25, 160-165. http://dx.doi.org/10.1016/b978-0-7020-3485-5.00034-6

[15] Massoumi, R. (2011) CYLD: A Deubiquitination Enzyme with Multiple Roles in Cancer. Future Oncology, 7, 285297. http://dx.doi.org/10.2217/fon.10.187

[16] Lin, P.Y., Fatteh, S.M. and Lloyd, K.M. (1987) Malignant Transformation in a Solitary Dermal Cylindroma. Archives of Pathology \& Laboratory Medicine, 111, 765-767.

[17] Munger, B.L., Graham, J.H. and Helwig, E.B. (1962) Ultrastructure and Histochemical Characteristics of Dermal Eccrine Cylindroma (Turban Tumor). Journal of Investigative Dermatology, 39, 577-595.

[18] Urbach, F., Graham, J.H., Goldstein, J. and Munger, B.L. (1963) Dermal Eccrine Cylindroma: A Histochemical, Electron Microscopic, and Therapeutic (X-Ray) Study. Archives of Dermatological, 88, 880-894.

[19] Crain, R.C. and Helwig, E.B. (1961) Dermal Cylindroma (Dermal Eccrine Cylindroma). American Journal of Clinical Pathology, 35, 504-515.

[20] Canedo, T., de Almeida, M.P., Cuzzi, T. and Ramos-e-Silva, M. (2010) Immunophenotypic Aspects of Cylindroma and Nodular Hidradenoma. Journal of the European Academy of Dermatology and Venereology, 24, 178-185. http://dx.doi.org/10.1111/j.1468-3083.2009.03398.x

[21] Cotton, D.W. and Braye, S.G. (1984) Dermal Cylindromas Originate from the Eccrine Sweat Gland. British Journal of Dermatology, 111, 53-61. http://dx.doi.org/10.1111/j.1365-2133.1984.tb04016.X

[22] Missall, T.A., Burkemper, N.M., Jensen, S.L. and Hurley, M.Y. (2009) Immunohistochemical Differentiation of Four Benign Eccrine Tumors. Journal of Cutaneous Pathology, 36, 190-196. http://dx.doi.org/10.1111/j.1600-0560.2008.00991.x

[23] Penneys, N.S. and Kaiser, M. (1993) Cylindroma Expresses Immunohistochemical Markers Linking It to Eccrine Coil. Journal of Cutaneous Pathology, 20, 40-43. http://dx.doi.org/10.1111/j.1600-0560.1993.tb01247.x

[24] Hashimoto, K. and Lever, W.F. (1969) Histogenesis of Skin Appendage Tumors. Archives of Dermatological, 100, 356-369. http://dx.doi.org/10.1001/archderm.1969.01610270098021

[25] Lever, W.F. and Hashimoto, K. (1966) Histogenesis of Various Skin Appendage Tumors in the Ligh of Histochemical and Electron Microscopical Findings (Eccrine Poroma, Eccrine Spiradenoma, Syringoma, Cylindroma and Calcified Epithelioma). Hautarzt, 17, 161-173.

[26] Layegh, P., Sharifi-Sistani, N., Abadian, M. and Moghiman, T. (2008) Brooke-Spiegler Syndrome. Indian Journal of Dermatology, Venereology and Leprology, 74, 632-634. http://dx.doi.org/10.4103/0378-6323.45109

[27] Parren, L.J., Bauer, B., Hamm, H. and Frank, J. (2008) Brooke-Spiegler Syndrome Complicated by Unilateral Hearing Loss. International Journal of Dermatology, 47, 56-59. 


\section{Submit or recommend next manuscript to SCIRP and we will provide best service for you:}

Accepting pre-submission inquiries through Email, Facebook, Linkedin, Twitter, etc A wide selection of journals (inclusive of 9 subjects, more than 200 journals)

Providing a 24-hour high-quality service

User-friendly online submission system

Fair and swift peer-review system

Efficient typesetting and proofreading procedure

Display of the result of downloads and visits, as well as the number of cited articles

Maximum dissemination of your research work

Submit your manuscript at: http://papersubmission.scirp.org/ 